\title{
Living Relationships Kokiri Ngatahi: The Treaty of Waitangi in the New Millennium.
}

\author{
Reviewed by Giselle Byrnes
}

\author{
Living Relationships Kokiri Ngatahi: The Treaty of Waitangi in the \\ New Millennium. \\ Ken S. Coates and P. G. McHugh \\ Wellington: Victoria University Press, 1998.
}

A decade ago New Zealand historiography-with the notable exception of Claudia Orange's The Treaty of Waitangi (1987)—could boast few texts devoted solely to the Treaty of Waitangi. In recent years, however, a new genre of criticism has arisen which is now an established part of Treaty discourse. Living Relationships Kokiri Ngatahi: The Treaty of Waitangi in the New Millennium, edited by Ken Coates and Paul McHugh, is a valuable and timely addition to this body of work. This book falls into three parts. The first is Coates' essay, 'International Perspectives on Relations with Indigenous Peoples'; the second is McHugh's 'Aboriginal Identity and Relations in North America and Australasia'; while the third section comprises commentaries on the two essays by a varied group of critics including Mason Durie, David Caygill, Roger Maaka, Bill Mansfield, Apirana Mahuika, Bill Oliver, Gina Rudland, Margaret Wilson and Joe Williams. The two main essays were commissioned by the Ministry of Justice, and as Patricia Scarr explains in the Preface, 'they do not focus on New Zealand's situation, though they refer to it; the task we set was to analyse what was happening outside this country' (9). Coates, a Canadian historian who is currently Dean of Arts at the University of New Brunswick (and who was professor of history at the University of Waikato at the time of writing), has researched and worked with various indigenous groups in the resolution of claims. McHugh, a respected New Zealand legal scholar now teaching at Cambridge, has published extensively in the field of aboriginal rights, with particular reference to North America and Australasia. While the two essays employ the language of the historian and the lawyer respectively, both Coates and McHugh support the resolution of historical grievances while pointing out the limitations of the current process. Coates argues that indigenous groups and governments have different (often conflicting) goals and are therefore 'talking past each other'. Indigenous groups, he contends, wish to assert their rights, and at a very fundamental level are seeking basic 'cultural survival'.

Kōtare 2, no. 2 (1999), pp. 68-71. 
Governments, on the other hand, while acknowledging past injustices, tend to want to settle these issues once and for all. McHugh, ever the lawyer, suggests that the claims settlement process inevitably 'locks' both partners into the politics of domination-one side wins while the other loses-which creates an addictive vertical battle for power, which he has described elsewhere. $\underline{1}$ He goes on to argue that the identities of 'the Crown' and 'the tribe' are themselves defined by this highly structured process. This critique of 'structuralism' essentially forms the basis of McHugh's argument, where he suggests that relationships are in fact much more complex than the structural model would have us believe. Both Coates and McHugh agree that such claim-based relations deny any expression of Maori identity which is not based on the tribal model. They also agree that the current process carries the assumption that the (full and final) settlement of the claim signals the end of the relationship. Coates and McHugh also make the following points: indigenous claims and the plight of indigenous peoples world-wide are losing support in the West; the situations of indigenous peoples in geographic and population terms vary considerably as do the responses to those situations; the need to shift the focus from full and final settlements to ones which renew the relationships between governments and indigenous groups to ensure the continuity of those relationships; that there is a movement away from the 'tribe' to 'ethnicity' as the key determinant of indigenous identity; and, perhaps most significantly, how these issues are at a crucial turning point in New Zealand.

The commentators largely agree with the critiques offered by Coates and McHugh. Mason Durie points out that the Treaty 'was always about the future' and that 'planning a future is a task for both partners'. David Caygill observes that governments, whatever their ideological underpinnings, have recognised that it is crucial to deal with at least the major claims before we can aspire to a healthy ongoing relationship between Maori and pakeha. Gina Rudland criticises McHugh's assumption that the Maori position is known or certain, while Roger Maaka warns the Crown against the influence of what he terms 'the rising tide of anti-tribalism'. Bill Mansfield suggests that we do not have a choice about the ongoing relationship between Maori and the Crown: the issue is the quality of those relationships. Apirana Mahuika takes issue with McHugh's assertion that tribal structures are an expression of Maori identity, rather than its source, arguing that such proposals are 'a pathway to disorder and dispute' because 'whakapapa is the heart and core of all Maori institutions'. Bill Oliver agrees with Coates' main concern and provides an interesting analysis of the ways in which pakeha support for the settlement process is becoming increasingly fragile, wryly observing how this unease is symbolised by 'the

Kōtare 2, no. 2 (1999), pp. 68-71. 
apostle of tribal capitalism, Tipene O'Regan, and...the exemplar of atavistic tribalism, Tame Iti'. Margaret Wilson presents a case for inclusion of Maori aspirations within any new constitutional arrangements. Joe Williams seems to point out that for some time Maori leaders have been suggesting a shift to more 'organic agreements' which emphasise the ongoing nature of the Treaty relationship.

Living Relationships is presented in a useful style that gives the reader the impression of attending a seminar where the dialogue has been well thought out in advance. For all the criticism that is currently directed at the Treaty claims process - that it is too expensive, too slow, or simply unnecessary-it has at least got historians, lawyers and politicians talking (and listening) to each other. This book is evidence of such dialogue. However, the main thesis of this book is that there is a need for more talking, more listening, and more consideration of the issues that concern both Maori and pakeha in resolving our differences and living together.

\section{Endnotes}

1 P.G. McHugh, 'Law, History and the Treaty of Waitangi', New Zealand Journal of History, 31,1 (1997): 38-57.

Kōtare 2, no. 2 (1999), pp. 68-71. 